\title{
OS DEVERES INDIVIDUAIS DOS CIDADÃOS NA CONSTITUIÇÃO FEDERAL DE 1988
}

\author{
Joshua Gomes Lopes ${ }^{1}$ \\ Ivson Antônio de Souza Meireles ${ }^{2}$
}

Resumo: Pesquisa sobre os deveres constitucionais individuais, enquanto categoria jurídica autônoma, à luz da Constituição Federal de 1988. Apresenta uma breve visão histórica dos deveres e da cidadania, analisando seus significados na Antiguidade clássica. Por fim, analisa os deveres individuais dos cidadãos presentes na Constituição Federal brasileira de 1988 e ventila a possibilidade de inclusão de um rol de deveres individuais no texto constitucional.

Palavras-chave: Deveres Fundamentais. Deveres Individuais dos Cidadãos. Constituição Federal de 1988. Teoria dos deveres. Antiguidade Clássica.

\section{THE INDIVIDUAL DUTIES OF CITIZENS IN THE BRAZILIAN FEDERAL CONSTITUTION OF 1988}

\begin{abstract}
It is a research on individual duties of citizens, as an autonomous legal category, based on the Federal Constitution of 1988. It presents a brief historical view of the duties and citizenship, analyzing their significance in classical antiquity. Finally, it analyzes the individual duties of citizens present in the Brazilian Federal Constitution of 1988 and proposes the possibility of including a list of individual duties in the constitutional text.
\end{abstract}

Keywords: Fundamental Duties. Individual Duties of Citizens. Federal Constitution. Theory of Duties. Classical Antiquity.

\footnotetext{
${ }^{1}$ Mestre em Ordem Jurídica Constitucional pela Universidade Federal do Ceará. Professor do Curso de Direito do Centro Universitário Inta - UNINTA, Sobral/CE. Currículo Lattes: http://lattes.cnpq.br/8114944054248958. Endereço postal: Rua Frei Mansueto 1500, Meireles, Fortaleza - CE. Email: jogomeslopes2@gmail.com

${ }^{2}$ Mestre em Direito Constitucional Público e Teoria Política pela Universidade de Fortaleza. Professor do Curso de Direito do Centro Universitário Inta - UNINTA, Sobral/Ce. Currículo Lattes: http://lattes.cnpq.br/1868632761849425. Endereço postal: Rua Nogueira Acioly 1634, Centro, Fortaleza - CE. Email:ivson.meireles@hotmail.com
} 


\section{INTRODUÇÃO}

Na segunda metade do primeiro século antes de Cristo, Marco Túlio Cícero, um dos maiores pensadores da Roma Antiga, proferiu as seguintes palavras a respeito dos deveres: “nada em nossa vida esquiva-se ao dever: observá-lo é virtuoso, negligenciá-lo, desonra.” (CÍCERO, 2002, p. 32). Estas palavras não foram ditas de forma vã; ao contrário, foram escritas como um conselho, um guia moral de Cícero a seu filho, que estudava em Atenas na época. Cícero, que dedicou a sua vida à política da República romana, acreditava que cada ação feita por um cidadão romano em prol da defesa e proteção de sua comunidade representava um exercício de virtudes cívicas e morais que conduziriam a um único objetivo: o máximo bem comum. (CÍCERO, 2002, p. 32).

Muitos séculos depois, a frase de Cícero - pelo menos no sentido pleno do que ele queria dizer - não possui mais o mesmo impacto de outrora. A vida virtuosa já não tem o mesmo valor que possuía na Antiguidade clássica, e os deveres acabaram sendo deixados de lado, a fim de dar lugar a um tempo novo: a “Era dos Direitos”. De acordo com Norberto Bobbio (2003, p. 33), a “Era dos Direitos” é marcada como um período em que se reivindica, a todo instante, que novas relações sociais e novos bens sejam apresentados para serem tutelados pelo Direito, de forma que se conceda ao indivíduo tudo aquilo que ele deseja. Embora haja certa preocupação quanto à concretização dessas demandas - uma vez que “à medida que as pretensões aumentam, a satisfação delas torna-se cada vez mais difícil” (BOBBIO, 2003, p. 32) -, parece que a tendência de uma intensa proliferação de novos direitos tornou-se bastante evidente.

O surgimento e a previsão normativa de novos direitos não é, em si, um problema, no entanto, atualmente opta-se por um grande enaltecimento dos direitos dos indivíduos em detrimento de seus deveres, de forma que ambas aparentam ser agora duas categorias completamente independentes e desconexas.

Toma-se, como exemplo, a escassa previsão dos deveres na Constituição Federal de 1988. Embora o capítulo I do Título II da Constituição de 1988 seja denominado “Dos direitos e deveres individuais e coletivos”, não há, em todo o art. 5º menção expressa a deveres individuais e coletivos dos cidadãos.

Esse contexto também reflete certo desinteresse pelo estudo dos deveres na ciência jurídica. Relegados a uma visão simplista que os compreende apenas como restrições aos direitos individuais, os deveres carecem não só de uma previsão mais contundente em todo o 
ordenamento jurídico pátrio, mas também como objeto de estudo teórico e doutrinário, tendo em vista ser um elemento indispensável na efetividade dos direitos fundamentais e na formação da verdadeira cidadania.

Assim, este trabalho tem o objetivo de fazer uma breve análise dos deveres individuais à luz da Constituição Federal de 1988, a partir de uma breve visão histórica, mostrando a importância e o sentido dos deveres e da cidadania na Antiguidade Clássica.

A metodologia deste trabalho consistiu em pesquisa bibliográfica, sendo utilizados livros, artigos de divulgação científica e publicações periódicas cujos temas estejam relacionados à temática dos deveres individuais e sua relação com a Constituição. Optou-se pela pesquisa qualitativa e exploratória, haja vista ser um tema relevante, porém, de escasso material doutrinário e jurisprudencial e de pouca abordagem em produções científicas. Acredita-se que o trabalho pode contribuir amplamente no estudo dos deveres e direitos fundamentais dentro do âmbito do Direito Constitucional.

\section{O ESQUECIMENTO DOS DEVERES}

Um dos efeitos negativos da "Era dos Direitos” é o fato de que a primazia quase absoluta da afirmação dos direitos fundamentais em face do Estado resultou numa evidente desconsideração jurídica dos deveres, especialmente no âmbito do direito constitucional. O escasso desenvolvimento teórico e dogmático dessa espécie normativa é o sinal mais claro dessa rejeição.

Na verdade, pode-se constatar que a ideia de dever foi paulatinamente perdendo força e importância após o seu auge no período da Antiguidade Clássica. Com o advento da modernidade e os ideais de afirmação e emancipação do homem, a noção de dever intrínseca ao agir humano foi sendo substituída pelo discurso de exaltação da autonomia e liberdade do indivíduo, valorizando assim os direitos decorrentes de sua condição natural.

Ocorre que essa autonomia absoluta da vontade individual operou uma profunda mudança na consciência de nossa civilização, de forma que, com o passar do tempo, ouviu-se falar muito mais de direitos do que de deveres. Ao dissociar essas duas realidades, a modernidade foi responsável por dar início a uma significativa relativização dos padrões éticos e por um enfraquecimento dos valores morais. (MAGALHÃES FILHO, 2006, p.129). 
De acordo com Corção (1967, p. 163), o humanismo moderno é egoísta em sua essência, porque representa, na verdade, uma inflação do eu-exterior. O autor identifica essa exaltação de si como a origem do individualismo moderno, cujo termo visa designar

[...] a teoria que faz prevalecer os direitos do indivíduo sobre o bem comum, mas antes disso designará coisa mais essencial: uma concepção do homem diversa da cristã, e traçada na perspectiva do que S. Paulo chama homem-exterior - concepção que tende para a supervalorização do indivíduo ou eu-exterior, e consequentemente tenderá para o materialismo e por fim para o desumanismo. (CORÇÃO, 1967, p. 163).

Isso significa que o individualismo parece estar diretamente relacionado à perda da noção de que o homem possui uma natureza social, entendida aqui como ação responsável dentro de uma comunidade. Johannes Messner (1970, p.127) afirma que o que faz do homem um ser social é o zelo para com os vínculos sociais que ele estabelece, "sobretudo com a comunidade familiar, a parentela, a nação e o Estado.” (MESSNER, 1970, p. 129).

Na medida em que a consciência do homem perde a percepção de seu dever de responsabilidade para com sua família, comunidade e nação, ele se volta para si e vive sob a letargia de um egoísmo ilusório. Desse modo, só se dará importância àquilo que represente um desejo ou um ganho ao indivíduo. O que requerer dele uma ação de dever responsável será rejeitado. (MAGALHÃES FILHO, 2006, p.137).

Sob essa perspectiva, é fácil entender o motivo dos deveres terem sido esquecidos nos âmbitos moral e jurídico da vida social. Os deveres impõem obrigações de ação ou omissão ao indivíduo, que o conduzem a um senso de proteção e conservação de sua comunidade. Com a expansão da mentalidade individualista na consciência de nossa civilização, não há nem mesmo espaço para discussões concretas em torno da importância do dever no agir humano, já que o indivíduo "tende a ser morno, cético ou prudente em relação à causa comum, ao bem comum, à boa sociedade ou à sociedade justa.” (BAUMAN, 2001, p.45).

No plano jurídico, a pouca relevância dos deveres enquanto espécie normativa é ainda mais evidente. Desde o advento do constitucionalismo - aqui entendido como o início de um movimento político, social e jurídico que, visando à limitação do poder arbitrário, conduz ao surgimento e à propagação de cartas constitucionais escritas (ZAGREBELSKY, 1998, p. 99) , a positivação dos deveres constitucionais sempre esteve em baixa prioridade em relação aos direitos constitucionais.

Veja-se, por exemplo, o caso das constituições liberais do século XVIII. Tanto a Constituição americana de 1787 quanto a Constituição francesa de 1791 possuíam um objetivo 
claro de resguardar os direitos oriundos da liberdade e do direito natural do homem, mas não há, em nenhuma delas, qualquer referência explícita aos deveres dos cidadãos. Também na Declaração dos Direitos do Homem e do Cidadão de 1789 também não há menção a deveres.

As constituições que representaram o período de ascensão do Estado social no início do século XX também não traziam um rol dedicado aos deveres constitucionais. Na Constituição mexicana de 1917, há uma breve menção às obrigações dos cidadãos mexicanos nos arts. 31 e 36, direcionadas aos serviços para com o Estado, como o serviço militar. (MÉXICO, 1917). Da mesma forma, a Constituição de Weimar de 1919 não traz menção explícita aos deveres, limitando-se a prever que os cidadãos têm a obrigação de prover serviços pessoais ao Estado e à comunidade, conforme consta em seu art. 133. (ALEMANHA, 1919).

Com o advento do período do pós-guerra, a situação praticamente não se alterou. A Constituição Italiana (1947), a Lei Fundamental da República Federal da Alemanha (1949), a Constituição Portuguesa (1976) e a Constituição Espanhola (1978) são alguns exemplos de textos constitucionais desse período que tratam, de maneira dominante, da dimensão dos direitos em detrimento dos deveres. (NABAIS, 2009, p.16).

No Brasil, a Constituição Federal de 1988 também traz posição muito semelhante. Ainda que existam menções específicas a deveres do cidadão espalhados pelo texto constitucional, como, por exemplo, o dever de proteção ao meio ambiente (art. 225) e o dever de assistência, criação e educação dos filhos pelos pais (art. 229), a temática dos deveres parece ter sido totalmente esquecida.

A situação se agrava ao analisar o título do Capítulo 1 do Título II da nossa Constituição Federal, qual seja “Dos Direitos e Deveres individuais e coletivos”. Não há, em todos os incisos do art. $5^{\circ}$, nenhuma menção explícita aos deveres dos cidadãos, sejam individuais ou coletivos. Todos os deveres presentes neste artigo surgem em decorrência dos direitos previstos, ou seja, são deveres acessórios a direitos principais.

Parece claro, portanto, que há realmente uma desconsideração geral, nos principais textos constitucionais do século XX, dos deveres individuais. A “Era dos Direitos” pode ter prejudicado ainda mais nessa questão, dada a ênfase demasiada nas particularidades e necessidades do indivíduo em detrimento dos valores da responsabilidade e do dever para com a comunidade. 
Ocorre que nem sempre foi assim. Um olhar histórico tende a revelar que em outros tempos, especialmente na Antiguidade clássica, os deveres tiveram um papel relevante na formação de um indivíduo enquanto cidadão.

\section{A RELAÇÃO ENTRE DEVERES E CIDADANIA NA ANTIGUIDADE CLÁSSICA}

A civilização greco-romana foi absolutamente única na história da humanidade. Nenhuma outra civilização antiga contribuiu mais para a formação política, histórica e cultural do Ocidente como ela, de modo que o historiador francês Fustel de Coulanges (2011, p.14) considerou Grécia e Roma do seguinte modo: “Nada, nos tempos modernos, se parece com a história delas. Nada, no futuro, poderá assemelhar-se a elas”. Dentre essas várias contribuições, as mais comumente citadas são a ideia de democracia, as instituições políticas (o Senado e a Bulé, por exemplo), a participação popular e a ideia de cidadania.

No entanto, antes mesmo da cidadania existir, já havia sido formada na Antiguidade a instituição primordial e basilar da sociedade: a Família. (COULANGES, 2011, p.109). A pequena sociedade doméstica, composta de governo - poder paterno -, moral e costumes próprios, constituiu-se como o berço da civilização e a origem fundamental da cidade. A própria ideia de direito encontra-se inicialmente enraizada dentro das relações cultivadas no seio familiar. (COULANGES, 2011, p.109).

É também na Família que o homem tem os primeiros contatos com os princípios morais, como a virtude e o bem. Segundo Coulanges (2011, p.109), a família da Idade Antiga era o próprio modelo do que viria a ser a sociedade, uma vez que

[...] cada família tem chefe, seu líder, como qualquer nação teria um rei; tem suas leis,
sem dúvida não escritas, mas gravadas pela crença religiosa no coração de cada
homem; tem sua justiça interna, superior à qual nenhuma outra há para que se possa
apelar. Tudo aquilo de que o homem tem rigorosa necessidade para a sua vida
material, ou para a vida moral, a família o possui. Não necessita de coisa alguma fora;
a família é um Estado organizado, uma sociedade que se basta a si mesma.

Além disso, é interessante notar também que a noção de dever surge a partir das relações familiares cotidianas e, especialmente, das crenças religiosas cultivadas no seio familiar. A religião doméstica - não organizada - foi a responsável por incutir no homem os primeiros traços de uma ideia moral, que se articulava através de pequenas obrigações domésticas, cujo significado estava ligado à memória dos antepassados e do cultivo da espiritualidade. (COULANGES, 2011, p.121). De acordo com Coulanges (2011, p.55), a ideia 
de dever pode ter surgido, nesse período, a partir da prática de duas obrigações domésticas muito comuns: o culto dos mortos e o fogo sagrado.

Para os antigos, os mortos eram considerados seres sagrados. A ideia de que, após a morte, todas as almas entravam na morada celeste não fazia parte da crença primitiva dos povos ocidentais. (COULANGES, 2011, p.22). Ao contrário, mesmo após a morte, acreditava-se que alma e corpo permaneciam associados, de modo que a sepultura significava a presença real, embora não visível, do morto. Assim, além da veneração, costumava-se oferecer alimentos, culto e sacrifícios em honra às almas dos antepassados. (COULANGES, 2011, p.31)

A oferta da refeição fúnebre e o culto aos mortos eram considerados deveres dos familiares, especialmente do pai, chefe da religião doméstica e responsável pela perpetuidade da tradição. (COULANGES, 2011, p.115). O não cumprimento desses deveres representava a negligência e o descuido dos vivos, que seriam punidos pela possibilidade do advento de doenças ou pela esterilidade do solo. Logo, não era possível imaginar como seria a dinâmica familiar sem a presença dos deveres para com os mortos. (COULANGES, 2011, p.115).

A segunda obrigação doméstica era a manutenção do fogo sagrado. O grego e o romano tinham o costume de ter em casa um altar com um pouco de cinza e carvões acesos. (COULANGES, 2011, p.34). Era dever do chefe da família conservar o fogo sagrado aceso, que representava a benevolência da divindade naquele lar. Oferendas e incenso eram colocados no fogo como súplica de proteção, favor e riqueza aos deuses. (COULANGES, 2011, p.34)

Por conseguinte, a manutenção do fogo constitui-se como um dever absolutamente necessário à sobrevivência do núcleo familiar. A extinção do fogo era o símbolo da extinção da própria família, pois já não estava mais amparada pelo olhar divino. (COULANGES, 2011, p.34). O fogo sagrado era o símbolo da religião doméstica e o sinal da prosperidade do lar.

As primeiras práticas dos deveres foram iniciadas, portanto, no contexto das tradições familiares. Coulanges (2011, p. 109 e 110) considera essa percepção relevante, pois, segundo ele, não é a cidade que define ou serve de modelo para a Família. A instituição familiar é muito anterior à formação da cidade, e foi ela que primeiro estabeleceu as regras, os princípios, as crenças e os deveres dos povos antigos.

Sobre o surgimento da cidade, Coulanges (2011, p. 161) entende que foi um fenômeno iniciado a partir da associação de pequenos grupos familiares e tribos, movidos pela necessidade de alcançarem objetivos comuns. Boa parte das tradições familiares foram preservadas, mas houve um processo natural de aumento da importância da cidade na vida da população. As 
cidades-estado, por exemplo, constituíram-se como o auge do crescimento econômico, social e político da cidade.

As cidades-estado - que se difundiram pelo Mediterrâneo a partir de núcleos originais da Grécia continental, da Ásia Menor e da Fenícia (PINSKY; PINSKY, 2014, p.32) permaneceram durante muito tempo como o mais significativo modelo de organização da coletividade humana, especialmente pela relação dialética que possuía com os indivíduos e, principalmente, com os seus cidadãos. Havia nelas uma forte integração com os seus habitantes, pelo simples fato de que pertencer à cidade "era participar de todo um ciclo da vida cotidiana, com seus ritos, costumes, regras, festividades, crenças e relações pessoais.” (PINSKY; PINSKY, 2014, p.32).

É interessante notar também que as cidades-estado possuíam um sentido comunitário muito mais profundo do que os Estados nacionais contemporâneos. (PINSKY; PINSKY, 2014, p.34). Para o cidadão grego e o cidadão romano, a cidade tornou-se a sua comunidade, ou seja, o espaço que dá sentido às suas ações no mundo, de sorte que esse cidadão realiza todas as suas aptidões e virtudes em vista da coletividade. (PINSKY; PINSKY, 2014, p.32). Isso quer dizer que, na Antiguidade clássica, o homem tinha uma ligação mais estreita com sua comunidade e, por isso, percebia que sua existência e seu agir importavam a ela.

Só na pólis se pode encontrar aquilo que abrange todas as esferas da vida espiritual e humana e determina de modo decisivo a sua estrutura. No período primitivo da cultura grega, todos os ramos da atividade espiritual brotam diretamente da raiz unitária da vida em comunidade. Poderíamos comparar isso a múltiplos regatos e rios que desembocassem num único mar - a vida comunitária - de que recebessem orientação, e refluíssem à sua fonte por canais subterrâneos e invisíveis. Descrever a cidade grega é descrever a totalidade da vida dos Gregos. Embora isto seja um ideal praticamente irrealizável, ao menos na forma usual de uma narração temporal progressiva e linear dos fatos históricos, a consideração daquela unidade é muito fecunda para todas e cada uma das suas esferas. A pólis é o marco social da história da formação grega. (JAEGER, 2001, p. 107)

De acordo com Manfredo Oliveira (1993, p. 21), não é natural para os gregos, por exemplo, considerar ou pensar o indivíduo de forma isolada. Ao contrário, a comunidade é que é o eixo central da reflexão de todo o pensamento clássico, porque se apresenta como elemento constitutivo (ontológico) do homem. Nas suas palavras:

A sociabilidade é vista no pensamento grego como algo constitutivo da essência humana, de tal modo que o homem, como ser essencialmente político, só na “comunidade política” (pólis) pode encontrar sua auto-efetivação. Só na pólis o homem conquista seu ser, realiza-se como homem: fora da comunidade política não 
há realização plena do ser-homem. Portanto, para o pensamento clássico, a situação natural do homem não é uma existência pré-política, mas precisamente a vida em sociedade, a vida inserida na comunidade política [...] (OLIVEIRA, 1993, p.21).

Na obra A Política, Aristóteles (1998, p.04 e 05) define o homem como um “animal cívico”, feito para a sociedade política, a quem foi dado pela natureza “senão o conhecimento desenvolvido, pelo menos o sentimento obscuro do bem e do mal, do útil e do nocivo, do justo e do injusto (...)”.Isso quer dizer que o homem é um ser político, que age politicamente na comunidade na qual está inserido, mediante a prática das virtudes.

O fim da sociedade civil é, portanto, viver bem; todas as suas instituições não senão meios para isso, e a própria Cidade é apenas uma grande comunidade de famílias e aldeias em que a vida encontra todos estes meios de perfeição e de suficiência. É isto o que chamamos uma vida feliz e honesta. A sociedade civil é, pois, menos uma sociedade de vida comum do que uma sociedade de honra e de virtude. (ARISTÓTELES, 1998, p.56)

Pode-se afirmar, portanto, que a cidadania na Antiguidade clássica possuía um sentido muito mais profundo do que em nossos dias, no sentido de que, além de poder participar da atividade política, o cidadão tinha consciência de que a cidade era a comunidade que lhe dava sentido de existência. Por isso, o espaço comunitário deveria ser preservado, as tradições deveriam ser zeladas e todo indivíduo deveria comprometer-se com o crescimento e a manutenção da cidade.

No caso dos cidadãos romanos, também eram detentores de uma variedade de direitos civis e políticos, mas também eram obrigados a cumprirem certos deveres. Alguns direitos civis e políticos eram: o direito de contrair matrimônio legítimo (ius conubii), o direito de resolver negócios de caráter particular (ius commercii), o direito de voto (ius suffragii), o direito de ser votado (ius honorum) e o direito de participar do sacerdócio (ius sacrorum). (GIORDANI, 1985, p.184).

Já os deveres estavam relacionados principalmente com o sentido cívico da manutenção do funcionamento da cidade e de sua defesa militar. Por exemplo, o Census era o dever que todo cidadão possuía de apresentar-se ao recenseamento; o Militia era a obrigação de prestar serviço militar e de defender a cidade em tempos de guerra, e o Tributum era o dever de contribuição direta proporcional à fortuna para sustentação das finanças. (GIORDANI, 1985, p.184).

O segundo aspecto é que, assim como em Platão e Aristóteles, a ideia de dever expressa por Cícero está intrinsecamente ligada à ideia de virtude. Conforme ele mesmo diz: "Negócios 
públicos ou privados, civis ou domésticos, ações particulares ou transações, nada em nossa vida esquiva-se ao dever: observá-lo, é virtuoso, negligenciá-lo, desonra.” (CÍCERO, 2002, p.32). Para Cícero (2002, p.33), a principal virtude que fundamenta a prática dos deveres é a honestidade, ou seja, o agir de acordo com a reta razão.

A virtude da honestidade desdobra-se em outras quatro virtudes essenciais para o surgimento dos deveres: a sabedoria, a justiça, a firmeza e a moderação. (CÍCERO, 2002, p.35). Cada uma delas incute nos indivíduos uma série de responsabilidades destinadas ao justo equilíbrio e à ordem da comunidade. É, portanto, a prática do bem por meio das virtudes que dá ao cidadão romano o sentido do dever. A prática da virtude é a ação que decorre no cumprimento do dever.

Nota-se que há uma grande preocupação de Cícero com as práticas morais da sociedade romana, visto que ele acredita que são elas que determinam diretamente a ascensão ou declínio da República. (CÍCERO, 2002, p.35). A voluptuosidade e o ócio são, para ele, os grandes responsáveis pelo enfraquecimento das instituições políticas nesse período, pois o cidadão romano passou a cultuar vícios em detrimento das virtudes. (CÍCERO, 2011, p.10)

Outro aspecto relevante da ideia de dever no pensamento ciceroniano é a relação entre a preservação daquilo que é coletivo com a defesa da pátria. Cícero entende que todo cidadão romano tem uma espécie de dívida para com a pátria, que investiu e colaborou na formação de cada um. (MARTINS, 2011, p.74). Desse modo, preservar aquilo que é comum à coletividade é retribuir tudo aquilo que a comunidade fez e continua fazendo pelo indivíduo.

A pátria não nos gerou nem educou sem esperança de recompensa de nossa parte, e só para nossa comodidade e para procurar retiro pacífico para a nossa incúria e lugar tranquilo para o nosso ócio, mas para aproveitar, em sua própria utilidade, as mais numerosas e melhores faculdades das nossas almas, do nosso engenho, deixando somente o que a ela possa sobrar para nosso uso privado. (CÍCERO, 2011, p.13).

Portanto, praticar as virtudes por meio dos deveres não seria somente um cumprimento de regras de direito, mas um emprego das "melhores faculdades” da alma de cada cidadão disposto a conservar, defender e contribuir com o crescimento da pátria romana. (MARTINS, 2011, p.74). Através desse pensamento, percebe-se que o cidadão romano é orientado a não ter um olhar individualista para si; ao contrário, deve sempre voltar-se para uma entidade única e maior, qual seja a sua comunidade, através da prática do bem e do cultivo da excelência moral.

Em síntese, ser cidadão no pensamento de Cícero é, acima de tudo, ser virtuoso. A cidadania não significa simplesmente possuir direitos, mas também ser responsável na busca 
de um aperfeiçoamento moral concreto e na prática de deveres que visem o bem comum da coletividade. As próprias palavras do autor romano concluem: “[...] deves saber que todos os que socorrem, salvam ou engrandecem a pátria têm no céu um lugar marcado e certo, no qual desfrutarão felicidade e beatitude sempiternas; porque nada é mais grato a Deus [...]” (CÍCERO, 2011, p.13).

Compreende-se, portanto, a razão da importância dos deveres para os antigos. A noção de dever está presente na consciência do homem grego e do romano, seja de forma mais evidente, ou não. O importante, na verdade, é a percepção dentro do pensamento clássico de que o indivíduo é sujeito de direitos, mas também possui responsabilidades e deveres, enquanto cidadão, para com sua comunidade.

\section{OS DEVERES DOS CIDADÃOS NA CONSTITUIÇÃO FEDERAL DE 1988}

Feita a digressão histórica sobre os deveres na Antiguidade clássica, analisa-se agora o modo como a Constituição Federal de 1988 aborda, em seu texto, os deveres constitucionais individuais, a partir da definição anteriormente dada.

Na história das constituições brasileiras, os deveres nunca gozaram de uma posição de destaque no texto constitucional. Ao contrário, sempre foram muito pouco mencionados, independentemente do regime político e da situação social, econômica e cultural do País. A Constituição Imperial de 1824, por exemplo, não faz praticamente nenhuma referência a deveres individuais, exceto pelo artigo 145, que prevê o dever dos brasileiros de pegarem em armas para defender o Império dos seus inimigos externos ou internos. (BRASIL, 1824).

Na Constituição de 1891, o §28 do artigo 72 menciona que ninguém poderá eximir-se do cumprimento de qualquer dever cívico, sem especificar, porém, quais seriam esses deveres. (BRASIL, 1891). Por sua vez, o artigo 86 prevê a obrigatoriedade de todo brasileiro prestar serviço militar, em defesa da Pátria e da Constituição, na forma indicada pelas leis federais. (BRASIL, 1891). Também na Constituição de 1934, há pouquíssima menção aos deveres. Citase, por exemplo, o artigo 109 que traz os deveres de voto e de alistamento e o artigo 163, que determina a todos os brasileiros o serviço militar, exceto as mulheres, e o juramento à bandeira nacional, na forma da lei. (BRASIL, 1934).

Até mesmo na Constituição considerada autoritária do Estado Novo, no qual deveres poderiam ter sido exaltados em detrimento dos direitos individuais, poucos deveres são 
encontrados. É o caso, por exemplo, do dever dos pais de promover a educação integral da prole (art. 125), do dever de ensino primário (art.130) e do dever de trabalhar (art. 136), bem como o dever de serviço militar e defesa da pátria (art.164). (BRASIL, 1937). Já na Constituição de 1946, podem ser mencionados o dever de voto e alistamento (art. 133), o dever de trabalhar (art. 145, parágrafo único), o dever de ensino primário (art.168, I) e o dever de serviço militar e defesa da pátria (art. 181). (BRASIL, 1946).

A Constituição de 1967 traz a previsão dos deveres de prestar serviço militar e outros encargos necessários à segurança nacional (art. 93), de voto e alistamento (art. 148, §1º e o dever de ensino (art. 168, §3º, II). (BRASIL, 1967). Com a inserção da Emenda constitucional $\mathrm{n}^{\circ} 1$ de 1969, os mesmos deveres foram mantidos, sendo alterados apenas os artigos que os constavam; passaram a ser previstos, respectivamente, pelos art. 92, art.147, $\S 1^{\circ}$ e art. 176, §3, II. (BRASIL, 1969).

A Constituição de 1988, por sua vez, reproduz alguns deveres já positivados nas constituições anteriores, como é o caso do dever de voto e alistamento (art. 14, §1 ${ }^{\circ}$, I), o dever de prestar serviço militar (art.143) e o dever de educação (art. 205). (BRASIL, 1988a). Por outro lado, inova ao prever, pela primeira vez, alguns deveres no texto constitucional, como, por exemplo, o dever de defesa e proteção do meio ambiente (art.225) ${ }^{3}$, o dever de assistência, criação e educação dos filhos pelos pais (art. 229) e o dever de amparo às pessoas idosas (art. 230). (BRASIL, 1988a).

Entretanto, nossa atual Constituição traz alguns problemas em relação à temática dos deveres. O primeiro deles é a já mencionada pouca expressão que os deveres constitucionais individuais possuem no texto constitucional. Apesar do aumento na quantidade de deveres positivados em relação às constituições anteriores, fica claro que ainda é um número muito reduzido em comparação com o grande número de direitos individuais que a Constituição prevê.

Porém, o maior problema diz respeito a uma questão sistemática. A Constituição de 1988 foi a primeira constituição brasileira a prever um rol único destinado a direitos e deveres individuais, qual seja o Capítulo I do Título II intitulado “Dos Direitos e Deveres Individuais e

\footnotetext{
${ }^{3}$ Aqui cabe uma importante observação. Reconhece-se que alguns deveres presentes na Constituição, tais como o dever de educação (art. 205) e o dever de defesa e proteção do meio ambiente (art. 225), foram concebidos pelo legislador constituinte, inicialmente, como deveres de prestação impostos ao Estado. Entretanto, entende-se que esses deveres não são prescrições exclusivas ao Estado, mas são igualmente destinadas a cada indivíduo e a toda coletividade. Exemplo disso é o fato de que a legislação ordinária, em respeito ao mandamento constitucional, tipificou como crime algumas condutas individuais relacionadas ao descumprimento desses dois deveres, como é o caso da Lei de Crimes Ambientais (Lei no 9.605/98) e o crime de abandono intelectual, tipificado no art. 246 do Código Penal.
} 
Coletivos”. (BRASIL, 1988a). Contudo, embora haja a previsão desse rol, não há, em todos os incisos do Art. 5ºneção explícita a deveres individuais dos cidadãos, exceto aqueles chamados deveres-direitos.

Todos os deveres presentes neste artigo surgem em decorrência de direitos previstos, ou seja, funcionam como um complemento aos direitos. É o caso, por exemplo, do inciso IV do Art. $5^{\circ}$, que diz ser livre a manifestação do pensamento, sendo vedado o anonimato. (BRASIL, 1988a). Ora, o dever que consta neste dispositivo, qual seja o de expressar ou deixar clara a identidade pessoal na manifestação do pensamento, só adquire sentido como um complemento ao direito que lhe deu causa. Um dever-direito não subsiste por si só. Também é o caso do dever de aviso prévio como um complemento ao direito de reunião pacífica (art. $5^{\circ}, \mathrm{XVI}$ ). (BRASIL, 1988a).

Não há, no entanto, uma única menção explícita a deveres individuais autônomos em todos os 78 incisos do art. 5 . Como é possível explicar a ausência dos deveres individuais dos cidadãos justamente no rol destinado a sua positivação? Ao consultar os anais da Assembleia Nacional Constituinte de 1987/88, percebe-se que, originariamente, o título do Capítulo I do Título II do texto constitucional não trazia a expressão “deveres”. No Anteprojeto Constitucional, elaborado pela Comissão Provisória de Estudos Constitucionais e apresentado na Assembleia Constituinte em 1986, o capítulo referente aos direitos e deveres denominavase simplesmente "Dos Direitos e Garantias”. (BRASIL, 1988b).

Com a apresentação dos substitutivos ao anteprojeto, o título do capítulo em questão foi sendo gradualmente alterado. A partir do Substitutivo 1, em agosto de 1987, passou a ser denominado “Dos Direitos Individuais”; no Substitutivo 2, em setembro de 1987, “Dos Direitos Individuais e Coletivos” e, em novembro do mesmo ano, na apresentação do Projeto A em Plenário, manteve o título anterior. (BRASIL, 1988b).

Entretanto, em 2 de fevereiro de 1988, constava, na ordem do dia do Plenário da Assembleia, o encaminhamento de votação da Emenda Substitutiva $n^{\circ} 2038$ ao projeto de Constituição, assinada pelo deputado constituinte Guilherme Afif Domingos e mais 279 deputados, que previa diversas alterações no Título II, destinado aos direitos e garantias fundamentais. Dentre essas alterações, estava a inserção do termo “deveres” no título do Capítulo I, que passaria a ser denominado “Dos Direitos e Deveres Individuais e Coletivos”. A Emenda foi aprovada, com 377 votos a favor, 56 votos contrários e 2 abstenções. (BRASIL, 1988c) 
Estranhamente, na ata da sessão em que ocorreu essa votação, consta que o deputado Ulysses Guimarães, presidente da Assembleia Nacional Constituinte, iria conceder a palavra ao autor da emenda, para que pudesse defendê-la antes de ser votada. Porém, isso não ocorreu, pois, segundo o presidente, o autor não estava inscrito para fazer a sustentação oral. Dessa forma, de acordo com os relatos apresentados no diário da Assembleia Constituinte, não houve nenhuma discussão a respeito da Emenda Substitutiva $n^{\circ} 2038$ antes de sua votação. (BRASIL, 1988c). Em nenhum outro documento da Constituinte foram encontradas referências ou discussões a respeito da inserção do termo “deveres” no título do Capítulo I do Título II da Constituição.

Diante do que foi exposto, é possível perceber como é restrita a abordagem que a nossa atual Constituição faz da temática dos deveres. O legislador constituinte limitou-se a positivar alguns poucos deveres - espalhados no texto de forma assistemática - e não previu um rol de deveres individuais onde deveria. Além disso, pela quase inexistência de propostas de emenda à Constituição sobre o assunto, percebe-se que há, na verdade, um grande desinteresse por essa discussão. A “Constituição cidadã” - termo dado pelo deputado Ulysses Guimarães à Constituição de 1988 (BRASIL, 1988d) - parece ter sido erigida a partir de uma concepção de cidadania que dá praticamente exclusividade aos direitos em detrimentos dos deveres dos indivíduos. O valor da liberdade enaltecido sobre o valor da responsabilidade.

\subsection{Da possibilidade de inclusão de um rol de deveres individuais na Constituição Federal de 1988}

Partindo da constatação de que os deveres individuais foram expressos de uma forma rasa e insuficiente no texto constitucional, discute-se agora a possibilidade de incluí-los no rol que inicialmente fora destinado a eles, qual seja o Capítulo I do Título II da nossa atual Constituição. Para tanto, é importante fazer um comparativo com outras constituições que prezaram por dar uma maior visibilidade aos deveres individuais em seus textos.

Conforme já visto anteriormente, a previsão de um rol destinado a deveres individuais nas mais diversas constituições não é muito comum. Algumas delas, como, por exemplo, a Constituição Americana de 1787, a Lei Fundamental Alemã de 1949 e a Constituição Francesa de 1958, praticamente não fazem referência alguma a deveres individuais. Por outro lado, outras cartas constitucionais já apresentam os deveres de uma forma mais concreta. 
A Constituição portuguesa de 1976, por exemplo, traz uma série de deveres constitucionais individuais, como o dever de educação dos filhos pelos pais (art.36), o dever de voto (art.49), o dever de defesa e promoção da saúde (art. 64), o dever de defesa do meio ambiente (art.66), o dever de preservação, defesa e valorização do patrimônio cultural (art.78) e o dever de defesa da pátria (art.276). (PORTUGAL, 1976). A maioria desses deveres está prevista na Parte I da Constituição, cujo título denomina-se “Direitos e deveres fundamentais”. Logo, ainda que em pouca quantidade, vê-se certa preocupação do legislador constituinte português em incluir os deveres no rol que fora destinado a eles.

Da mesma forma, a Constituição italiana de 1947 e a Constituição espanhola de 1978 prevêem alguns deveres individuais em partes específicas dos seus textos. No caso da Constituição espanhola, estão inseridos no Título I - “De los derechos y deberes fundamentales” - os seguintes deveres: o dever de educação básica (art. 27.4), o dever de defender a Espanha (art. 30), o dever de trabalhar (art. 35), o dever de assistência dos pais aos filhos (art. 39.3) e o dever de conservação do meio ambiente (art. 45.1). (ESPANHA, 1978). Já a Parte I da Constituição italiana - "Diritti e doveri dei cittadini” - traz o dever de educação dos filhos (art.30), o dever de instrução básica (art. 34), o dever de votar (art.48), o dever de defesa da pátria (art.52), o dever de contribuir para as despesas públicas (art.53) e o dever de fidelidade à República e à Constituição (art.54). (ITÁLIA, 1947).

Há que se destacar, todavia, o modelo utilizado pela atual Constituição da Índia. No início de sua promulgação, em 1950, a Constituição indiana não trazia um rol específico de deveres destinados aos cidadãos. Com o advento da $42^{\circ}$ Emenda em 1976, foi adicionado ao texto a Parte IV, intitulada "Fundamental Duties”, acrescentando assim o art. 51-A, que elencava 10 deveres individuais. (ÍNDIA, 1950). Posteriormente, com a 86º Emenda de 2002, mais um dever foi adicionado a esse artigo, totalizando 11 deveres destinados aos cidadãos indianos.

FUNDAMENTAL DUTIES

51A. It shall be the duty of every citizen of India-

(a) to abide by the Constitution and respect its ideals and institutions, the National Flag and the National Anthem;

(b) to cherish and follow the noble ideals which inspired our national struggle for freedom;

(c) to uphold and protect the sovereignty, unity and integrity of India;

(d) to defend the country and render national service when called upon to doso;

(e) to promote harmony and the spirit of common brotherhood amongst all the people of India transcending religious, linguistic and regional or sectional diversities; to renounce practices derogatory to the dignity of women; 
(f) to value and preserve the rich heritage of our composite culture;

(g) to protect and improve the natural environment including forests, lakes, rivers and wild life, and to have compassion for living creatures;

(h) to develop the scientific temper, humanism and the spirit of inquiry and reform;

(i) to safeguard public property and to abjure violence;

(j) to strive towards excellence in all spheres of individual and collective activity so that the nation constantly rises to higher levels of endeavour and achievement;

(k) who is a parent or guardian to provide opportunities for education to his child or, as the case may be, ward between the age of six and fourteen years. (ÍNDIA, 1950).

Segundo Kurian Joseph (2016, p.02, tradução nossa), juiz da Suprema Corte indiana, a positivação de deveres individuais na Constituição da Índia decorre da ideia de que "um regime democrático não pode ser bem-sucedido quando os cidadãos estão preocupados apenas com seus direitos e não estão dispostos a serem participantes ativos no processo de governança, assumindo responsabilidades através dos deveres e dando o melhor pelo seu país.” Nesse sentido, a proposta da $42^{\mathrm{a}}$ Emenda era inserir deveres, fundamentados na dignidade humana, que pudessem "balancear os direitos dos cidadãos, a fim de os tornarem mais responsáveis no desenvolvimento da nação.” (JOSEPH, 2016, p.02, tradução nossa).

Além de possuir um artigo inteiro destinado aos deveres individuais, pode-se afirmar que o grande mérito que a Constituição indiana tem é o de reconhecer a cidadania a partir do binômio direito-dever; a percepção de que os deveres têm o papel de resguardar os direitos e os valores de uma sociedade. Desse modo, a positivação dos deveres deve representar para os cidadãos indianos um compromisso assumido com sua nação.

Outro país que traz em sua constituição um artigo totalmente destinado a deveres individuais é a Nigéria. A Constituição nigeriana de 1999, promulgada com o intuito de restabelecer o regime democrático no país e de proteger suas instituições, prevê no artigo 24 um rol de seis deveres individuais: o dever de obediência à Constituição e de respeito aos seus ideais e institutos (art. 24, “a”), o dever de ajudar a ampliar o poder e o prestígio da Nigéria, bem como de defendê-la (art. 24, “b”), o dever de respeito à dignidade e aos direitos dos outros cidadãos (art. 24, “c”), o dever de contribuir pelo bem-estar da comunidade (art. 24, “d”), o dever de manutenção da lei e da ordem (art. 24, “e”) e o dever de pagar impostos (art. 24, “f”). (NIGÉRIA, 1999).

Esses foram alguns exemplos de constituições que poderiam servir de modelo para a nossa atual Constituição de 1988, no que diz respeito à positivação dos deveres individuais dos cidadãos. Esse comparativo não significa que nossa Constituição deve reproduzir igualmente o 
que outras fizeram; na verdade, pretende apresentar alternativas ao já mencionado problema da ausência de um rol de deveres no texto constitucional.

Uma das possibilidades seria a inserção dos deveres individuais por meio da adição de emenda constitucional com novos incisos ao art. $5^{\circ}$ da CF/88. Já que este artigo representa todo o Capítulo I do Título II, daria sentido à proposta inicial do legislador constituinte em fazer dele um rol único destinado aos direitos e deveres individuais e coletivos. Outra possibilidade seria a inclusão de um artigo adicional ao Art. $5^{\circ}$ - um artigo 5- A, por exemplo -, nos moldes da Constituição indiana, que inserisse, por meio de emenda constitucional, um rol específico de deveres individuais.

Além da guarda dos deveres já existentes, poderiam também ser incluídos na Constituição de 1988, por exemplo, o dever de pagar impostos, o dever de defesa da pátria, o dever de defesa e preservação do patrimônio público e cultural, o dever de trabalhar, o dever de contribuir com o bem-estar da comunidade, etc.

\section{CONSIDERAÇÕES FINAIS}

Diante de tudo aquilo que foi exposto neste trabalho, é possível constatar a importância da temática acerca dos deveres individuais dos cidadãos, muito embora estejam esquecidos não só em nossa Constituição, mas também como um objeto de estudo teórico em si. O objetivo maior desta pesquisa é apresentar os deveres como uma categoria imprescindível para a vida do homem em sociedade, na medida em que se mostram como elementos necessários junto aos direitos individuais.

Em síntese, percebe-se a necessidade de mudar a perspectiva de nossa sociedade a respeito dos deveres. Resgatar, na medida do possível, a visão que os antigos possuíam sobre o tema e fazer com que cada um compreenda a importância de suas ações na defesa e na preservação do bem comum. Estudar os deveres é ter a consciência de que é preciso sair de si e, muitas vezes, abdicar de interesses e satisfações próprias em vista do bem do outro.

O indivíduo, reconhecido constitucionalmente em suas particularidades, está também necessariamente inserido numa comunidade; possui vínculos sociais que fazem dele um ser livre e ao mesmo tempo responsável. Não é possível, portanto, pensar esse indivíduo a partir de um sistema que confere total primazia - quase exclusividade - a direitos em face de deveres, bem como à liberdade em face da responsabilidade. 


\section{REFERÊNCIAS}

ALEMANHA. Constituição de Weimar de 1919. Disponível em: http://www.zum.de/psm/weimar/weimar_vve.php . Acesso em: 12 fev.2018.

ARISTÓTELES. A Política. Tradução Roberto Leal Ferreira. $2^{\mathrm{a}}$ Ed. São Paulo: Martins Fontes, 1998.

BAUMAN, Zygmunt. Modernidade Líquida. Tradução Plínio Dentzien. Rio de Janeiro: Jorge Zahar Ed., 2001.

BRASIL. Anais da Assembleia Nacional Constituinte de 1987/88. Disponível em: http://www.senado.gov.br/publicacoes/anais/constituinte/AfonsoArinos.pdf. Acesso em: 11 fev.2018.

BRASIL. Anais da Assembleia Nacional Constituinte de 1987/88. Disponível em: http://www.senado.gov.br/publicacoes/GeneseConstituicao/pdf/genese-cf-1988-1.pdf\#cap1r. Acesso em: 12 fev.2018.

BRASIL. Anais da Assembleia Nacional Constituinte de 1987/88. Disponível em: http://www2.camara.leg.br/atividade-legislativa/plenario/discursos/escrevendohistoria/25anos-da-constituicao-de-1988/constituinte-1987-1988/pdf/Ulysses\%20Guimaraes\%20\%20DISCURSO\%20\%20REVISADO.pdf/n Acesso em: 12 fev.2018.

BRASIL. Constituição brasileira de 1824. Disponível em: http://www.planalto.gov.br/ccivil_03/constituicao/constituicao24.htm . Acesso em: 10 fev.2018.

BRASIL. Constituição brasileira de 1891. Disponível em: https://www.planalto.gov.br/ccivil_03/constituicao/constituicao91.htm . Acesso em: 10 fev.2018.

BRASIL. Constituição brasileira de 1934. Disponível em: http://www.planalto.gov.br/ccivil_03/Constituicao/Constituicao34.htm . Acesso em: 10 fev.2018.

BRASIL. Constituição brasileira de 1937. Disponível em: http://www.planalto.gov.br/ccivil_03/constituicao/constituicao37.htm . Acesso em: 10 fev.2018.

BRASIL. Constituição brasileira de 1946. Disponível em: http://www.planalto.gov.br/ccivil_03/constituicao/constituicao37.htm . Acesso em: 10 fev.2018. 
BRASIL. Constituição brasileira de 1967. Disponível em: http://www.planalto.gov.br/CCivil_03/Constituicao/Constituica067.htm . Acesso em: 11 fev.2018.

BRASIL. Emenda Constitucional $\mathrm{n}^{0} 01$ de 1969. Disponível em: http://www.planalto.gov.br/ccivil_03/Constituicao/Emendas/Emc_anterior1988/emc0169.htm. Acesso em: 11 fev.2018.

BRASIL. Constituição brasileira de 1988. Disponível em: http://www.planalto.gov.br/ccivil_03/constituicao/constituicao.htm . Acesso em: 11 fev.2018.

BRASIL. Diário da Assembleia Nacional Constituinte do dia 2 de fevereiro de 1988. Disponível em:

http://imagem.camara.gov.br/prepara.asp?selDataIni=02/02/1987\&selDataFim=05/10/1988\& opcao=1\&selCodColecaoCsv=R Acesso em: 12 fev.2018.

BOBBIO, Norberto. A era dos direitos. Tradução Carlos Nelson Coutinho. Nova Ed. Rio de Janeiro: Elsevier, 2004.

CÍCERO, Marco Túlio. Dos deveres. Tradução Alex Marins. São Paulo: Editora Martin Claret, 2002.

CÍCERO, Marco Túlio. Da República. Tradução Amador Cisneiros. $2^{\mathrm{a}}$ Ed. São Paulo: Edipro, 2011.

CORÇÃO, Gustavo. Dois Amores, Duas Cidades. Vol.II. São Paulo: Editora Agir, 1967.

COULANGES, Fustel de. A Cidade Antiga: estudo sobre o culto, o direito e as instituições da Grécia e de Roma. Tradução José Cretella Jr. e Agnes Cretella. $2^{\mathrm{a}}$ Ed. São Paulo: Editora Revista dos Tribunais, 2011.

ESPANHA. Constituição Espanhola de 1978. Disponível em: http://www.congreso.es/consti/. Acesso em: 15 fev.2018.

GIORDANI, Mário Curtis. História de Roma. 8ª Ed. Petrópolis: Editora Vozes, 1985.

ÍNDIA. Constituição Indiana de 1950 . Disponível em: http://lawmin.nic.in/olwing/coi/coienglish/coi-4March2016.pdf . Acesso em: 17 fev.2018.

ITÁLIA. Constituição Italiana de 1947. Disponível em: https://www.senato.it/documenti/repository/istituzione/costituzione.pdf. Acesso em: 15 fev.2018.

JAEGER, Werner Willhelm. Paidéia: a formação do homem grego. Tradução de Artur M. Parreira. $4^{\text {a }}$ Ed. São Paulo: Editora Martins Fontes, 2001.

KURIAN, Joseph. Transcrição de discurso sobre os deveres fundamentais na Constituição Indiana. Disponível em: http://www.thehindu.com/opinion/op-ed/Expanding-the-Idea-ofIndia/article14488980.ece. Acesso em: 17 fev.2018. 
MAGAlHÃES FILHO, Glauco barreira. Teoria dos valores jurídicos: uma luta argumentativa pela restauração dos valores clássicos. Belo Horizonte: Mandamentos, 2006.

MARTINS, Janaina de Paula. De ferro e flexível: A noção de dever imposta pela sociedade segundo as ponderações de Cícero, Platão e Aristóteles. Jus Humanum: Revista Eletrônica de Ciências Jurídicas e Sociais, v. 1, n. 1, ISSN 2238-2143, 2011, p.74. Disponível em: http://revistapos.cruzeirodosul.edu.br/index.php/jus_humanum/article/view/30 . Acesso em: 10 fev.2018.

MESSNER, Johannes. Ética Social. Tradução de Alípio Maia Castro. São Paulo: Editora Quadrante, 1970.

MÉXICO. Constituição mexicana de 1917. Disponível em: http://www.diputados.gob.mx/LeyesBiblio/htm/1.htm . Acesso em: 12 fev.2018.

NABAIS, José Casalta. O dever fundamental de pagar impostos: contributo para a compreensão constitucional do estado fiscal contemporâneo. Coimbra: Almedina, 2009.

NIGÉRIA. Constituição Nigeriana de 1999. Disponível em: http://www.nigerialaw.org/ConstitutionOfTheFederalRepublicOfNigeria.htm. Acesso em: 17 fev.2018.

OLIVEIRA, Manfredo Araújo de. Ética e sociabilidade. São Paulo: Loyola, 1993.

PINSKY, Jaime; PINSKY, Carla Bassanezi, (orgs.). História da cidadania. 6ªEd. São Paulo:

Editora Contexto, 2014.

PORTUGAL. Constituição Portuguesa de 1976. Disponível em: https://www.parlamento.pt/Legislacao/Paginas/ConstituicaoRepublicaPortuguesa.aspx. Acesso em: 15 fev.2018.

ZAGREBELSKY, Gustavo. Diritto Constituzionale: Il Sistema delle Fonti del Diritto. 1.ed. v.1. Torino:Unione Tipografico- Editrice Torinese, 1998. 